\title{
Metabolic Dependence of the Critical Hemolytic Volume of Human Erythrocytes: Relationship to Osmotic Fragility and Autohemolysis in Hereditary Spherocytosis and Normal Red Cells*
}

\author{
Robert I. WeEd † ANd Anthony J. Bowdler $\ddagger$ \\ (From the Departments of Radiation Biology and Biophysics and of Medicine, University of \\ Rochester School of Medicine and Dentistry, Rochester, N.Y.)
}

Erythrocytes from patients with hereditary spherocytosis (HS) undergo changes in cation and lipid content when incubated in vitro under sterile conditions for 24 hours. These are accompanied by changes in cell volume, osmotic fragility, and the critical volume at which hemolysis of the cell occurs. Normal red cells have been found to undergo similar changes but with a longer time scale, the normal taking 36 to 48 hours to achieve the degree of change found in the spherocyte at 24 hours.

The osmotic fragility of the erythrocyte depends on the relationship of the osmotically active intracellular contents of the cell, which determine the cell volume, to the area of the nondistensible membrane. Consequently, the shape of the cell has appeared important to many authors $(1-4)$, since the relative thickness of the cell depends on the ratio of the volume to the available surface area of the membrane.

A further phenomenon that is characteristic of the HS cell is that of marked autohemolysis on in vitro incubation (5-7). The mechanism is poorly understood, although it clearly bears a re-

* Submitted for publication September 9, 1965 ; accepted March 22, 1966.

Supported in part by the United States Atomic Energy. Commission at the University of Rochester Atomic Energy Project, Rochester, N. Y.

† Recipient of U. S. Public Health Service research grant HE 06241-05.

Address requests for reprints to Dr. Robert I. Weed, Dept. of Radiation Biology and Biophysics, University of Rochester School of Medicine and Dentistry, Rochester, N. Y. 14620.

$¥$ Buswell Fellow in Medicine during the period of this investigation; present address: University College Hospital Medical School, University Street, London, W.C.1, England. lationship to changes in osmotic fragility and is known to be inhibited by the provision of suitable metabolic substrate during incubation.

Both osmotic fragility and autohemolysis of the erythrocytes have been shown to be increased in most cases of hereditary spherocytosis. In 1954 Selwyn and Dacie (6) presented evidence that the mean cell volume was actually decreased during the second 24-hour period of in vitro incubation. They concluded that in vitro hemolysis was in some way associated with a decrease in surface area of the cells.

Reed and Swisher $(8,9)$ and Prankerd (10) have demonstrated that in vitro incubation of $\mathrm{HS}$ erythrocytes is associated with an abnormal loss of lipid from the affected cells. Reed and Swisher (8) showed that when this lipid loss reached approximately $20 \%$ there was a net loss of potassium from the cells. In 1957 Bertles (11) observed an increased rate of influx of sodium into HS cells. More recently, Jacob and Jandl (12) have suggested that increased sodium permeability is the major lesion resulting in decreased in vitro and in vivo survival of such cells. These authors have suggested that accumulation of intracellular sodium causes swelling of HS cells during in vitro incubation that is aggravated by the addition of ouabain and predisposes these cells not only to increased autohemolysis but perhaps also to destruction in the spleen. There is an apparent disparity between this view and the Selwyn and Dacie observation of cell shrinkage on incubation in vitro. Selwyn and Dacie suggested that HS cells are predisposed to loss of membrane surface area (6), which would be the probable consequence of the decrease in cell lipids described by Reed and Swisher $(8,9)$ and Prankerd $(10)$. The study reported here was undertaken in an at- 
tempt to reconcile the divergent views concerning the in vitro behavior of the hereditary spherocyte.

This investigation has been directed towards the following aspects of the problem:1) the measurement of the critical hemolytic volume of normal and $\mathrm{HS}$ cells under various conditions of incubation, especially in relation to the effects of added metabolic substrates; 2) the relationship between the critical hemolytic volume and changes in cell volume, lipid content, and cation composition of the cell; 3) consideration of the relevance of these findings to changes in osmotic fragility and to autohemolysis induced by sterile incubation in vitro; and 4) observations on the morphologic concomitants of the observed biochemical and physiological changes.

\section{Methods}

Blood. Blood samples were obtained from ten hematologically normal adults and from five splenectomized patients with HS. Splenectomized patients with normal reticulocyte counts were chosen to avoid inclusion of young cells in the erythrocyte populations studied. Only defibrinated normal and HS blood was used for 1) 24hour incubations before osmotic fragility tests by the method of Parpart and co-workers $(13)$; 2) 48-hour autohemolysis studies as described by Young, Izzo, Altman, and Swisher (7); and 3) studies of the critical hemolytic volume of normal cells after 36 to 48 hours of incubation. Either defibrinated blood or blood collected into $\mathrm{Na}_{2}$ EDTA was used for 24-hour studies of cation content, cell volume, autohemolysis, and critical hemolytic volume of both normal and HS cells. The final concentration of $\mathrm{Na}_{2}$ EDTA was $5 \times 10^{-8}$ mole per $\mathrm{L}$ of plasma chosen to prevent coagulation but not to provide a concentration sufficiently in excess of plasma $\mathrm{Ca}^{++}+\mathrm{Mg}^{++}$ to produce alterations such as those described by Garby and De Verdier (14) for red cell glycolytic rate when 5 to $10 \mathrm{mM}$ free $\mathrm{Na}_{2}$ EDTA was present. Studies of red cell glycolytic rates on donors used for the present studies were carried out by Reed and Swisher (9) who found no evidence of increased glycolytic rate attributable to $\mathrm{Na}_{2}$ EDTA. Simon and Ways (15) have shown that EDTA has no effect on autohemolysis of normal cells. Hoffman (16) has pointed out that EDTA has no effect on cation transport in red cells unless present during osmotic hemolysis, whereas Lepke and Passow (17) have made similar observations on $\mathrm{K}^{+}$permeability.

In addition, we carried out five measurements of erythrocyte $\mathrm{Ca}^{++}$on trichloroacetic acid extracts of $\mathrm{NaCl}$ washed normal cells examined fresh and after incubation. The measurements were made with a Perkin-Elmer atomic absorption flame photometer. The results for normal red cells were as follows: fresh, defibrinated $2.3 \pm 1.1$ (SD) $\times 10^{-17}$ mole per cell, and fresh $\mathrm{Na}_{2}$ EDTA (5 mmoles per L plasma) $2.2 \pm 0.8$ (SD) $\times 10^{-17}$ mole per cell.
After 24 hours of incubation the value for defibrinated cells was $4.8 \pm 1.0(\mathrm{SD}) \times 10^{-17}$ mole per cell and for $\mathrm{Na}_{2}$ EDTA cells, $5.4 \pm 2.1$ (SD) $\times 10^{-17}$ mole per cell. $\mathrm{Ca}^{++}$measurements of one sample of $\mathrm{HS}$ blood yielded fresh values of $3.0 \times 10^{-17}$ mole per cell and $3.1 \times 10^{-17}$ mole per cell for defibrinated and EDTA cells, respectively. After 24 hours of incubation with glucose the values were $3.7 \times 10^{-17}$ and $4.4 \times 10^{-17}$ mole per cell for defibrinated and EDTA cells, respectively. Thus, the concentrations of EDTA employed did not seem to remove cellular $\mathrm{Ca}^{++}$. No influence of $\mathrm{Na}_{2}$ EDTA vs. defibrination was encountered in 24-hour studies of autohemolysis of either normal or HS cells, nor was there any influence of the method of collection on critical hemolytic volume measurements made immediately or after 24 hours' incubation. Therefore, the results for 24 -hour cell volume autohemolysis, critical hemolytic volume, and cation content include data on both defibrinated and $\mathrm{Na}_{2}$ EDTA blood. However, the decrease in critical hemolytic volume that occurred in normal cells incubated without glucose for 36 to 48 hours, which were similar to HS cells incubated for 24 hours, seems to be prevented to some extent by the presence of $\mathrm{Na}_{2}$ EDTA; therefore, all of the incubations that were carried out for longer than 24 hours employed defibrinated blood.

$p H$. In both the $\mathrm{Na}_{2}$ EDTA and defibrinated normal and $\mathrm{HS}$ blood the initial $\mathrm{pH}$ was 7.7 to 7.8 , falling at 24 hours to values of 7.0 to 7.2 in incubations to which glucose had been added and remaining at 7.3 to 7.5 in incubations to which no glucose was added. Thirty-six-hour incubations of normal cells resulted in a further $\mathrm{pH}$ drop to 6.9 to 7.0 in glucose-supplemented incubations. Murphy (18) has called attention to the fact that red cell anaerobic glycolysis may be partially inhibited by lowered $\mathrm{pH}$. However, in the present studies $\mathrm{pH}$ was not controlled because the $\mathrm{pH}$ remained at or close to 7.4 in the incubations to which no glucose was added. It was these incubations that produced the pathologic cellular alterations. In addition, one purpose of the study was to investigate the mechanism of hemolysis in the conventional autohemolysis test in which $\mathrm{pH}$ is not controlled (7).

In some studies, $\mathrm{pH}$ of glucose-supplemented cells was maintained at 7.4 by utilizing a low hematocrit (20\%) and checking the $\mathrm{pH}$ of the blood at 8-hour intervals, readjusting plasma or serum $\mathrm{pH}$ with $0.1 \mathrm{~N} \mathrm{NaOH}$ when necessary. These studies demonstrated that the protective effect of glucose in preventing the changes in critical hemolytic volume was evident at $\mathrm{pH} 7.4$, as well as the lower $\mathrm{pH}$.

Incubation mixtures. Experimental incubation mixtures were composed of red blood cells that occupied 38 to $45 \%$ of the relative volume of the suspension, autologous serum or plasma containing $5 \times 10^{-8} \mathrm{M} \mathrm{Na} \mathrm{NaDTA}_{2}$, and either $30 \mathrm{mM}$ glucose, $30 \mathrm{mM}$ glucose $+1 \times 10^{-4} \mathrm{M}$ ouabain, $1 \times$ $10^{-4} \mathrm{M}$ ouabain, or an equivalent $\left(\frac{1}{20}\right)$ volume of $1 \% \mathrm{NaCl}$ added instead of glucose. Incubations were carried out in polypropylene flasks under sterile incubation conditions at $37^{\circ} \mathrm{C}$.

Cell sizing and critical hemolytic volume determination. Mean cell volumes at varying external tonicities were 
determined by analysis of volume distribution curves obtained with a model B Coulter electronic particle counter and either a model B plotter or a 400-channel analyzer. The red cells were diluted into phosphatebuffered $\mathrm{NaCl}$ solution to give a final concentration of 20 to 40,000 per $0.5 \mathrm{ml}$. In each case, the mean cell size was calculated from the mean "window" or channel of the plot by using a calibration factor as described by Brecher and associates (19). The calibration factor was evaluated independently each day by use of the microhematocrit in conjunction with the total red cell count. Because of the extreme rapidity of water movement through the membrane and the marked dilution of these cells (1 to 50,000 ) a new osmotic equilibrium volume is achieved almost immediately. This volume remains stable for at least 10 to 15 minutes in salt concentrations above those which produce hemolysis. However, in $\mathrm{NaCl}$ concentrations that are hemolytic, lysis secondary to the osmotic swelling beyond the critical volume results in loss of hemoglobin and cellular ion content resulting in an initial shrinkage. The maximal immediate mean cell volume that is measured in the various $\mathrm{NaCl}$ concentrations is taken as the critical hemolytic volume. In Figure $1, A, B, C$, and $D$ represent, respectively, the volume distribution of fresh normal cells in $1 \%$ buffered $\mathrm{NaCl}$, their maximal volume in $0.425 \% \mathrm{NaCl}$, and the volume distribution of lysed and shrunken cells in 0.4 and $0.3 \% \mathrm{NaCl}$. In $0.4 \%$, with more than $50 \%$ hemolysis, the decrease in mean cell volume is composed of a population of small lysed cells and a population of swollen unlysed cells, but the upper limit of the latter has not increased from $0.425 \%$. Therefore, selection of the volume in $0.425 \%$ as the critical hemolytic volume by virtue of its having a larger mean than that for $0.40 \% \mathrm{NaCl}$ does not obscure further swelling, even though the mean volume in $0.40 \%$ is based on a bimodal distribution. However, since repeated osmotic lysis is necessary to remove all the hemoglobin from red cells $(20)$, the residual hemoglobin in ion permeable, once hemolyzed cells results in reswelling and "rehemolysis" after the initial shrinkage. This is a predictable phenomenon based on the colloid osmotic effect of the residual hemoglobin in the leaky cell and is illustrated by $E$ in Figure 1, which shows reswelling 30 minutes after lysis in $0.30 \% \mathrm{NaCl}$. Therefore, to avoid variability associated with reswelling and to detect the salt concentration that represented the peak of the osmotic swelling curve, all of the measurements were made immediately upon dilution of the blood into the salt solution. Although there is considerable variability in the values of the cell volumes in salt concentrations that are lytic in contrast to nonhemolytic salt solutions, the former fall below the maximum if determined within 30 seconds.

The instrument provides a true measure of the volume of erythrocytes that has undergone osmotic lysis. For example, the volume of normal cells and ghosts, at a tonicity of $0.3 \% \mathrm{NaCl}$, was accurately determined by the Coulter counter. This was established by comparing the ratio of mean cell volume in $0.30 \% \mathrm{NaCl}$ to mean cell volume in $1.0 \% \mathrm{NaCl}$ by use of the Coulter counter, by
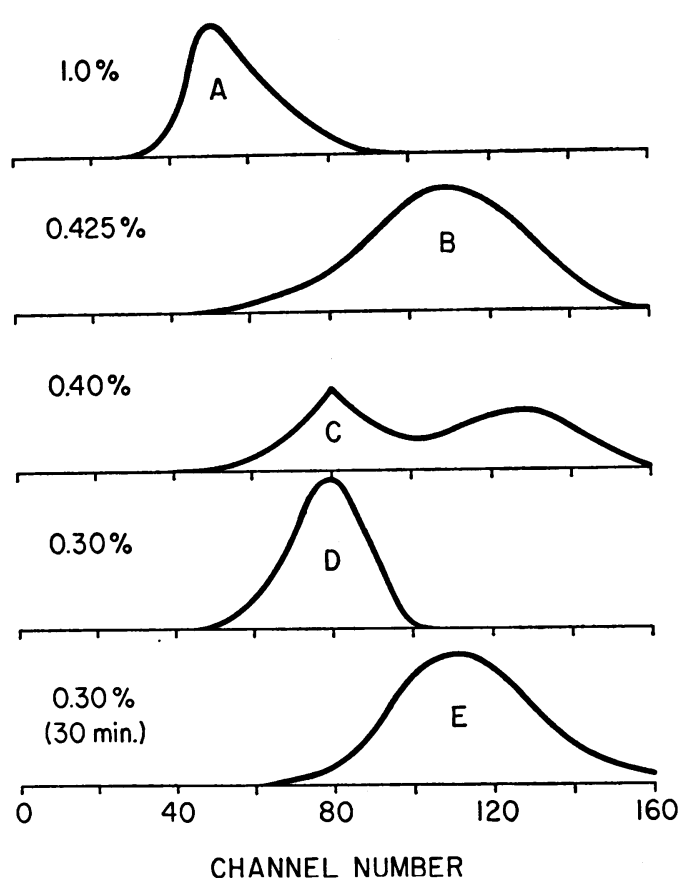

Fig. 1. VOLUME distribution CURVES OF FRESH NORMAL ERYTHROCYTES AT DIFFERING TONICITIES OF NACL-PO, BUfFEr. The blood was diluted 1:50,000 and the distribution analyzed with a Coulter counter and a 400-channel analyzer. The curves represent relative particle frequency vs. channel number at various dilutions of one blood sample. $\mathrm{A}=1 \%$, immediate plot; $\mathrm{B}=0.425 \%$, immediate plot; $\mathrm{C}=0.40 \%$, immediate plot; $\mathrm{D}=0.30 \%$, immediate plot; and $E=0.30 \%$, plotted after standing for 30 minutes at room temperature.

the microhematocrit method, and by measurement of the dilution space of radioactive ${ }^{181}$ I-iodinated serum albumin. For these studies, to avoid the problem of changing volume with reswelling of the cells hemolyzed in $0.3 \% \mathrm{NaCl}$, all of the readings were obtained at approximately 30 minutes when the cells had reswollen to their critical volume. Values for this ratio obtained with a sample of normal erythrocytes completely hemolyzed in $0.3 \% \mathrm{NaCl}$ were, respectively, $1.79,1.77$, and 1.71 .

Cation composition and mean cell volume. Mean cell volume as expressed in Table III was determined by microhematocrit and red cell counts using the Coulter counter. These determinations were carried out on fresh blood as well as incubated samples at the time of removal for measurement of cation content. Cation determinations were carried out by measurements of sodium and potassium with a Baird-Atomic flame photometer after washing the cells with a cold $\left(4^{\circ} \mathrm{C}\right)$ solution containing $0.1 \mathrm{M} \mathrm{MgCl} 2+0.05 \mathrm{M}$ Tris buffered at $\mathrm{pH} 7.4$. Although Valberg, Holt, Paulson, and Szivek (21) suggested loss of $\mathrm{Na}^{+}$by washing of red cells with isosmolar $\mathrm{MgCl}_{2}$, the values obtained in the present study for fresh normal cells are in substantial agreement with their val- 
ues, perhaps because a hypertonic wash solution was employed in the present studies.

$A T P$. Adenosine triphosphate was measured by the firefly tail, luciferin-luciferase system described by McElroy and Seliger (22). We added $10 \mu 1$ of red blood cells washed in $1 \% \mathrm{NaCl}$ to $10 \mathrm{ml}$ of distilled water, placed them in a boiling water bath for $1 \frac{1}{2}$ minutes, chilled them in an ice bath, and either measured immediately or froze them. The assay itself was carried out in a Nuclear-Chicago liquid scintillation counter according to the method of Tosteson, Cook, and Blount (23) and Tal, Dickstein, and Sulman (24) modified to use standard vials and to record counts between 10 and 34 seconds after mixing.

Photographs. Phase photomicrographs were taken of fresh and incubated spherocytic erythrocytes. Samples to be photographed were prepared before incubation by centrifugation twice at $250 \times g$ for 10 minutes to remove platelet-rich plasma. The latter was then freed of leukocytes, platelets, and particulate matter by centrifugation at $20,000 \times g$ for 30 minutes. The red cells were washed twice with $1 \% \mathrm{NaCl}$ to complete removal of leukocytes and platelets, then resuspended in the clear plasma. Rouleaux formation promptly occurred in both normal and HS samples treated in this fashion. Before photography one drop of blood was mixed with a drop of $1 \%$ $\mathrm{NaCl}$ to break up the rouleaux, and the preparation was examined wet between siliconized slides and coverslips. Electron micrographs were prepared by gluteraldehyde then osmium fixation of the blood cells and mounting in epon and sectioning.

\section{Results}

Autohemolysis and osmotic fragility. Table I summarizes the autohemolysis tests carried out on spherocytic blood in this study after 24 hours of gentle mixing and after 48 hours of incubation in sterile test tubes without shaking.

In all of the described experimental situations using blood from five normal donors, hemolysis was less than $1 \%$ in all samples incubated for 24 hours with gentle agitation and less than $3 \%$ in the 48-hour tube autohemolysis tests. The HS incubations, however, were in accord with the

TABLE I

Per cent autohemolysis of hereditary spherocytes

\begin{tabular}{lcr}
\hline \hline & 24 hours* & \multicolumn{1}{c}{48 hours $\dagger$} \\
\hline Glucose & $1.3 \pm 0.5 \ddagger$ & $3.0 \pm 1.8$ \\
Glucose and ouabain & $2.3 \pm 1.1$ & $5.4 \pm 2.9$ \\
No additive & $3.9 \pm 1.7$ & $17.1 \pm 2.3$ \\
Ouabain alone & & $16.4 \pm 4.6$
\end{tabular}

* Four determinations.

$\dagger$ Five determinations.

$\ddagger$ Mean values \pm standard error are given.
OSMOTIC FRAGILITY CHANGES IN HEREDITARY SPHEROCYTES AFTER INCUBATION

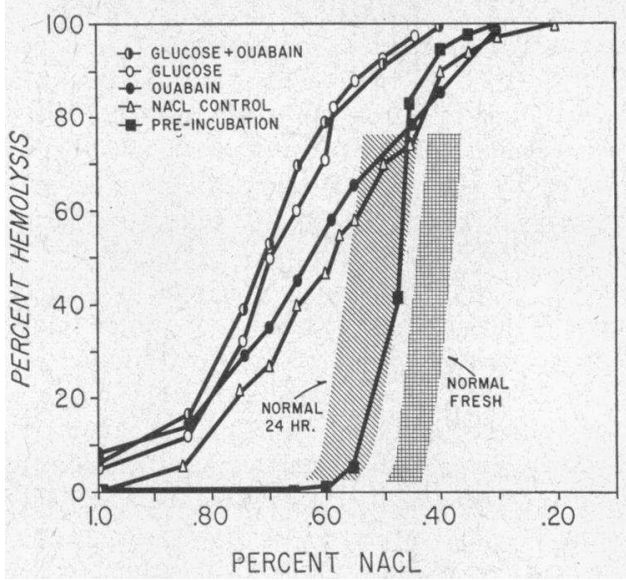

Fig. 2. EFFECT OF ADDITIVES ON OSMOTIC FRAGILITY OF A SAMPLE OF HEREDITARY SPHEROCYTOSIS BLOOD INCUBATED 24 Hours. Added glucose concentration was 0.03 mole per $\mathrm{L}$ and ouabain, $1 \times 10^{-4}$ mole per $\mathrm{L}$.

previous experience of others (5-7) in that the addition of glucose protected the spherocytic cells against the hemolysis seen in the incubations without added metabolic substrate. Although the addition of ouabain appears to increase slightly the 48-hour hemolysis of HS blood with glucose, this effect at both 24 and 48 hours is minimal compared with the significant protection against hemolysis conferred by glucose even in the presence of ouabain. The latter finding is at variance with the findings of Mohler (25), who demonstrated no protection by glucose in the presence of ouabain. Two of Mohler's experimental conditions differed from ours, continuous mixing of the blood and a lower concentration of ouabain $\left(2.5 \times 10^{-5} \mathrm{~mole}\right.$ per L). These may contribute to the discrepancy. Defibrinated blood was used for the autohemolysis in both studies.

Figure 2 illustrates a typical pattern of osmotic fragility of spherocytes, which occurs after 24 hours of incubation. Identical relative patterns were seen in studies of blood from five other HS patients. The fragilities do not correspond to the findings in the autohemolysis test. The cells to which glucose was added appear to show a greater increase in osmotic fragility than the cells to which no glucose had been added. This increase is related presumably to a combination of increase in cellular cation content (Table III) and to increased cellular $\mathrm{Cl}^{-}$, which will be anticipated be- 
cause of the decreased ionization of hemoglobin as $\mathrm{pH}$ falls. This observation of increased fragility upon incubation with glucose was previously pointed out by Selwyn and Dacie (6). Addition of ouabain does not seem to influence these findings significantly in either circumstance.

ATP levels. Mohler (25) presented evidence that ATP utilization by HS cells is greater than normal even in the presence of ouabain; therefore, these levels were compared after 24 hours of incubation. Table II summarizes these results along with data from parallel incubations of normal cells. The presence of glucose appears to have maintained ATP levels in both the spherocytes and the normal cells between 50 and $68 \%$ of preincubation values. This was true whether ouabain was present or not, although the variability precludes any precise comparison. In the nonsupplemented cells, however, the ATP had disappeared at 24 hours. The actual activity of the nonsupplemented incubations by the firefly assay ranged from 0 to $5 \%$ at 24 hours. Because of the possibility of a small reading from ADP, the values have been reported $<5 \%$. The similarity of the relative 24-hour ATP values for normal and HS cells supplemented with glucose is consistent with observations of Keitt (26).

Cation content. Table III compares the cation composition per cell of normal and HS cells before and after 24 hours of incubation in the presence and absence of glucose and ouabain. The initial (preincubation) HS values were not significantly different from values for $\mathrm{K}^{+}$and $\mathrm{Na}^{+}$of normal cells $(p>0.2)$. This observation agrees with the studies of Selwyn and Dacie (6) on HS cells from splenectomized patients. In both normal and HS cells, incubation without glucose, with ouabain only added, and with glucose plus ouabain resulted in highly significant $(\mathrm{p}<0.001)$ losses of $\mathrm{K}^{+}$and gains of $\mathrm{Na}^{+}$by comparison with the respective fresh cells. The normal cells treated with ouabain alone or metabolically depleted appeared to be unchanged in total cation content with the gain of $\mathrm{Na}^{+}$equaling the loss of $\mathrm{K}^{+}$. The values for total cation content are not significantly different from the fresh values. By contrast, incubated but nonsupplemented HS cells incubated without glucose lost more $\mathrm{K}^{+}$. This difference between $\mathrm{K}^{+}$content per cell of HS and normal cells incubated without glucose is highly
TABLE II

Erythrocyte ATP levels

\begin{tabular}{lcr}
\hline & \multicolumn{2}{c}{24 hours } \\
\cline { 2 - 3 } & \multicolumn{1}{c}{ Normal } & \multicolumn{1}{c}{ HS* } \\
\hline Glucose & $68 \pm 13 \dagger$ & $62 \pm 25$ \\
Glucose +ouabain & $58 \pm 13$ & $54 \pm 35$ \\
& $(\mathrm{~N}=5)$ & $(\mathrm{N}=4)$ \\
No additive & $<5$ & $<5$ \\
& $(\mathrm{~N}=8)$ & $(\mathrm{N}=4)$ \\
\hline
\end{tabular}

${ }^{*} \mathrm{HS}=$ hereditary spherocytosis.

t Values are expressed as the mean per cent of initial ATP levels \pm standard error. The mean preincubation value for normal cells was $2.1 \pm 0.3(\mathrm{SE}) \times 10^{-16}$ mole per cell and $1.8 \pm 0.4$ for the HS cells. $\mathrm{N}$ is the number of determinations.

significant $(p<0.01)$, whereas the difference between their total cation content is significant at the $\mathrm{p}<0.05$ level. The addition of ouabain to HS cells incubated without added glucose resulted in a cation and volume pattern similar to that seen in the nonsupplemented cells. The HS cells to which both glucose and ouabain were added gained sodium but appeared to lose less potassium than the nonsupplemented cells $(\mathrm{p}<0.05)$, and thus their total cation content exceeded that of the nonsupplemented cells, with or without ouabain $(\mathrm{p}<0.001)$.

Mean cell volume. Table III also indicates the mean cell volume of the spherocytic cells under each of the incubation circumstances as measured by hematocrit and red cell count done on the whole blood initially and at the end of each incubation period. Analysis of the volume versus total cation data of Table III reveals a highly significant $(p<0.001)$ correlation between the mean cell volume of fresh and incubated normal cells as well as fresh and incubated HS cells and the total cation content of the cells. The individual correlation coefficients $(r=0.60$ and 0.32 , respectively, for normal and HS), however, suggest that the cation content was not the only factor determining cell volume. The differences between the correlation coefficients for the HS versus normal populations or the regression lines $(b=3.36$ and 1.4 for normal and HS, respectively) are of borderline significance $(p=0.05)$ but suggest a poor correlation of volume and cation content in HS cells. In this regard, it is quite clear that the spherocytes to which glucose had been added 
TABLE III

Cation content and mean cell volume of normal and HS erythrocytes*

\begin{tabular}{|c|c|c|c|c|c|}
\hline & $\mathrm{K}^{+}$ & $\mathrm{Na}^{+}$ & $\mathrm{Na}^{+}+\mathrm{K}^{+}$ & $\begin{array}{l}\text { Volume in } \\
\text { plasma }\end{array}$ & $\mathrm{N}$ \\
\hline \multicolumn{6}{|l|}{ Normal } \\
\hline $\begin{array}{l}\text { Fresh } \\
\text { 24-hour glucose } \\
\text { 24-hour glucose } \\
\quad+\text { ouabain }\end{array}$ & $\begin{array}{l}9.38 \pm 0.54 \\
9.24 \pm 0.44 \\
7.70 \pm 0.36\end{array}$ & $\begin{array}{l}1.02 \pm 0.44 \\
1.20 \pm 0.93 \\
3.44 \pm 1.49\end{array}$ & $\begin{array}{l}10.4 \pm 0.54 \\
10.8 \pm 0.43 \\
11.1 \pm 0.44\end{array}$ & $\begin{array}{r}97.9 \pm 3.0 \\
99.8 \pm 2.3 \\
103.7 \pm 2.7\end{array}$ & $\begin{array}{r}11 \\
10 \\
8\end{array}$ \\
\hline $\begin{array}{l}\text { 24-hour no additive } \\
24 \text {-hour ouabain alone }\end{array}$ & $\begin{array}{l}7.64 \pm 0.57 \\
6.81 \pm 0.63\end{array}$ & $\begin{array}{l}3.04 \pm 0.22 \\
3.62 \pm 0.32\end{array}$ & $\begin{array}{l}10.7 \pm 0.44 \\
10.6 \pm 0.92\end{array}$ & $\begin{array}{r}102.0 \pm 2.9 \\
95.3 \pm 3.3\end{array}$ & $\begin{array}{r}10 \\
3\end{array}$ \\
\hline \multicolumn{6}{|l|}{ HS } \\
\hline $\begin{array}{l}\text { Fresh } \\
\text { 24-hour glucose } \\
\text { 24-hour glucose } \\
\quad+\text { ouabain }\end{array}$ & $\begin{array}{l}8.47 \pm 1.07 \\
8.84 \pm 0.22 \\
6.72 \pm 0.47\end{array}$ & $\begin{array}{l}1.23 \pm 0.18 \\
1.61 \pm 0.11 \\
3.86 \pm 0.10\end{array}$ & $\begin{array}{l}10.06 \pm 0.65 \\
10.67 \pm 0.36 \\
10.56 \pm 0.16\end{array}$ & $\begin{array}{r}92.9 \pm 2.2 \\
98.2 \pm 1.6 \\
103.1 \pm 2.4\end{array}$ & $\begin{array}{l}8 \\
9 \\
9\end{array}$ \\
\hline $\begin{array}{l}\text { 24-hour no additive } \\
\text { 24-hour ouabain alone }\end{array}$ & $\begin{array}{l}5.61 \pm 0.45 \\
5.20 \pm 0.54\end{array}$ & $\begin{array}{l}3.12 \pm 0.22 \\
3.55 \pm 0.30\end{array}$ & $\begin{array}{l}8.76 \pm 0.45 \\
9.04 \pm 0.48\end{array}$ & $\begin{array}{l}96.3 \pm 3.2 \\
87.4 \pm 4.5\end{array}$ & $\begin{array}{l}9 \\
3\end{array}$ \\
\hline
\end{tabular}

* Cation values are expressed as moles per cell $\times 10^{-15} \pm \mathrm{SE}$. Mean corpuscular volume in plasma is expressed in microns \pm SE. The determinations were made on blood from ten normal subjects and five patients with hereditary spherocytosis. Two separate determinations were made on some of the HS patients. $\mathrm{N}$ is the number of determinations.

$(\mathrm{p}<0.01)$ as well as the glucose plus ouabain cells $(p<0.01)$ were larger than the HS cells that had not been supplemented with glucose. The latter had apparently lost sufficient potassium to result in a decrease in total cation content from the fresh cells.

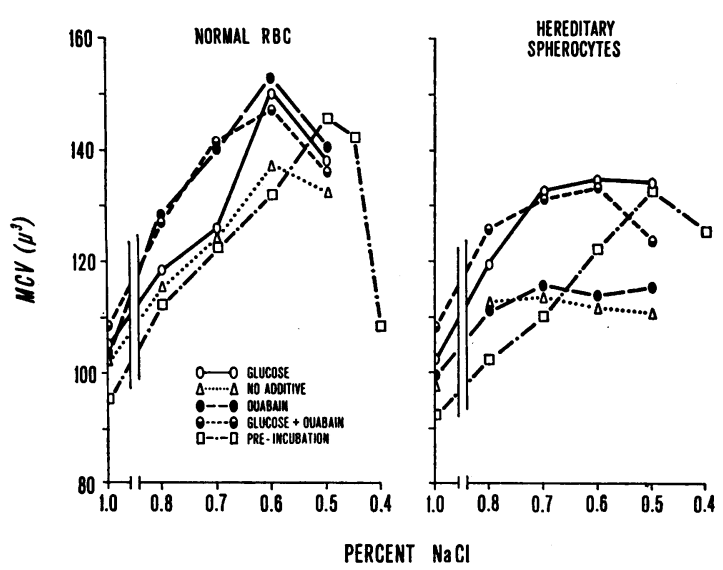

Fig. 3. Mean cell volumes calculated from volUME DISTRIBUTION CURVES AT DIFFERING TONICITIES OF $\mathrm{NACl}_{\mathrm{L}}-\mathrm{PO}_{4}$ BUFFER. The left portion represents normal blood mean values determined on six normal blood samples examined fresh, after 24 hours of incubation without additive, with glucose, and with glucose plus ouabain. Normal bloods incubated without additive or with only ouabain added were not different and, therefore, the latter is omitted from the graph. The right portion represents mean values from similar studies of blood from five hereditary sperocytosis patients. $\mathrm{MCV}=$ mean cell volume; $\mathrm{RBC}=$ red blood cells.
Critical hemolytic volume. The left section of Figure 3 represents the mean cell volume at various tonicities of normal red blood cells, both fresh and incubated, as derived from the volume distribution data provided by the Coulter counter. The right section of the Figure represents similar

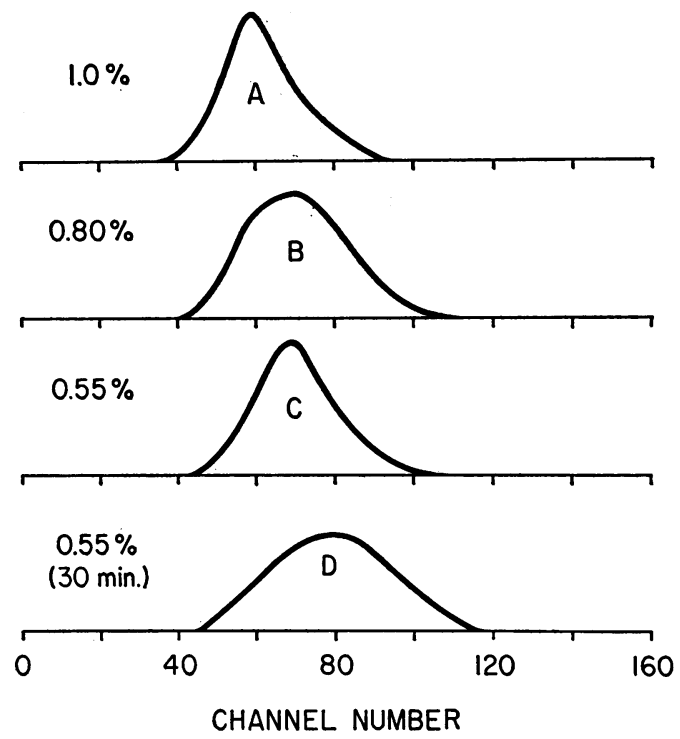

Fig. 4. Volume distribution curves in NaCl-PO, BUFFER OF A HEREDITARY SPHEROCYTOSIS RED CELL SAMPLE INCUBATED 24 HOURS WITHOUT ADDED GLUCOSE. The curves represent relative particle frequency vs. channel number. $\mathrm{A}=1.0 \%$, immediate plot; $\mathrm{B}=0.80 \%$, immediate plot; $\mathrm{C}=0.55 \%$, immediate plot; and $\mathrm{D}=0.55 \%$, plotted after standing for 30 minutes at room temperature. 
TABLE IV

24-hour change in critical hemolytic volume $(\mathrm{CHV})^{*}$

\begin{tabular}{lcc}
\hline & Normal & CHV \\
& CHV \\
\hline Glucose & $+5.5 \pm 1.0$ & $+1 \pm 3$ \\
Glucose + ouabain & $+6.9 \pm 1.1$ & $+2 \pm 4$ \\
No additive & $+5.5 \pm 1.3$ & $-15 \pm 4$
\end{tabular}

* Mean ( \pm standard error) changes in critical hemolytic volume of normal and HS blood after 24 hours' incubation, expressed as per cent of preincubation value.

data obtained by examination of the volume distribution of HS cells, both fresh and incubated. Since it has been shown that the Coulter counter reflects a true estimate of cell volume, even after osmotic lysis of cells in $0.30 \%$ sodium chloride, the maximal or critical hemolytic volume is indicated by the point at which the curves reach a maximum. Beyond that point the curves decrease as a consequence of loss of cellular contents, secondary to hemolysis. The maximal value represents the mean of the volumes of cells still swelling plus those which have hemolyzed. Thus, the peak of the fresh normal cell curve falls within a narrow range of salt concentrations, in contrast to the flattened peak of incubated HS cells that hemolyzed over a wider range of salt concentrations. Figure 4 represents the volume distribution curves of HS cells incubated for 24 hours without glucose. Comparison of B $(0.80 \%)$, in which hemolysis begins, with $\mathrm{C}(0.55 \%)$, in which hemolysis is nearly complete, reveals little change in volume or distribution. These patterns explain the flat HS curve in Figure 3 and, in contrast to fresh normal cells (Figure 1, C), no inhomogeneity is seen in partially hemolytic salt concentrations. In Figure 4, D, the reswelling after lysis is seen at 30 minutes. The volume, however, although slightly larger than Figure $4, \mathrm{~B}$, is still markedly decreased as anticipated from the loss of lipid (9).

Three features of the curves in Figure 3 deserve special comment. 1) The critical volume of fresh HS cells is decreased, as pointed out by Guest in 1948 (27). 2) It is evident that incubating normal cells for 24 hours results in some increase in their volume in $1 \%$ buffered saline, but the swelling response to hypotonicity is essentially unchanged after this period of incubation, regardless of the addition of glucose and ouabain. The critical hemolytic volume of normal cells incubated for 24 hours with or without glucose does not appear to change or may actually increase slightly. Similarly, after 24 hours of incubation the glucose and glucose plus ouabain-supplemented HS cells appear to demonstrate a slight increase in critical hemolytic volume. 3) The ouabain-treated and nonsupplemented HS cells, however, demonstrated a striking decrease in critical hemolytic volume, as indicated in the lower part of the right portion of Figure 3. Table IV summarizes the 24-hour critical hemolytic volume data. Figure 5, which represents the mean of three determinations, illustrates that after 36 hours of incubation without supplementary glucose normal cells also show a decrease in critical hemolytic volume, which is prevented by the addition of glucose.

Morphologic changes. Figure 6 is a phase photomicrograph of fresh HS cells and illustrates that many of the cells are biconcave discs with an evident light central area. In contrast to normal cells, however, several spherocytes appear crenated, even in freshly drawn blood. Incubation for 24 hours with glucose produces an increase in the number of crenated forms without a decrease in volume. Incubation without added metabolic sub-

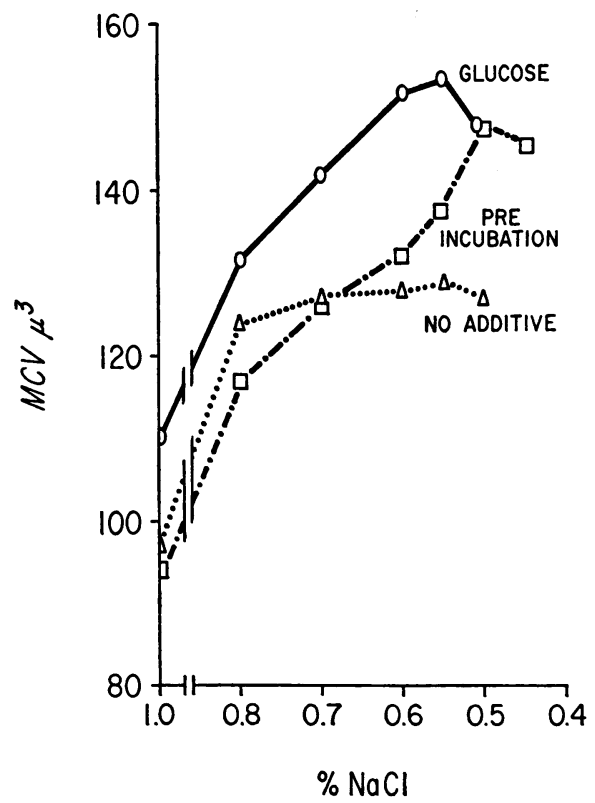

Fig. 5. Mean Cell volumes at varying tonicities OF NACL-PO4 BUFFER OF NORMAL ERYTHROCYTES INCUBATED FOR 36 HOURS. Values represent means of three determinations. 


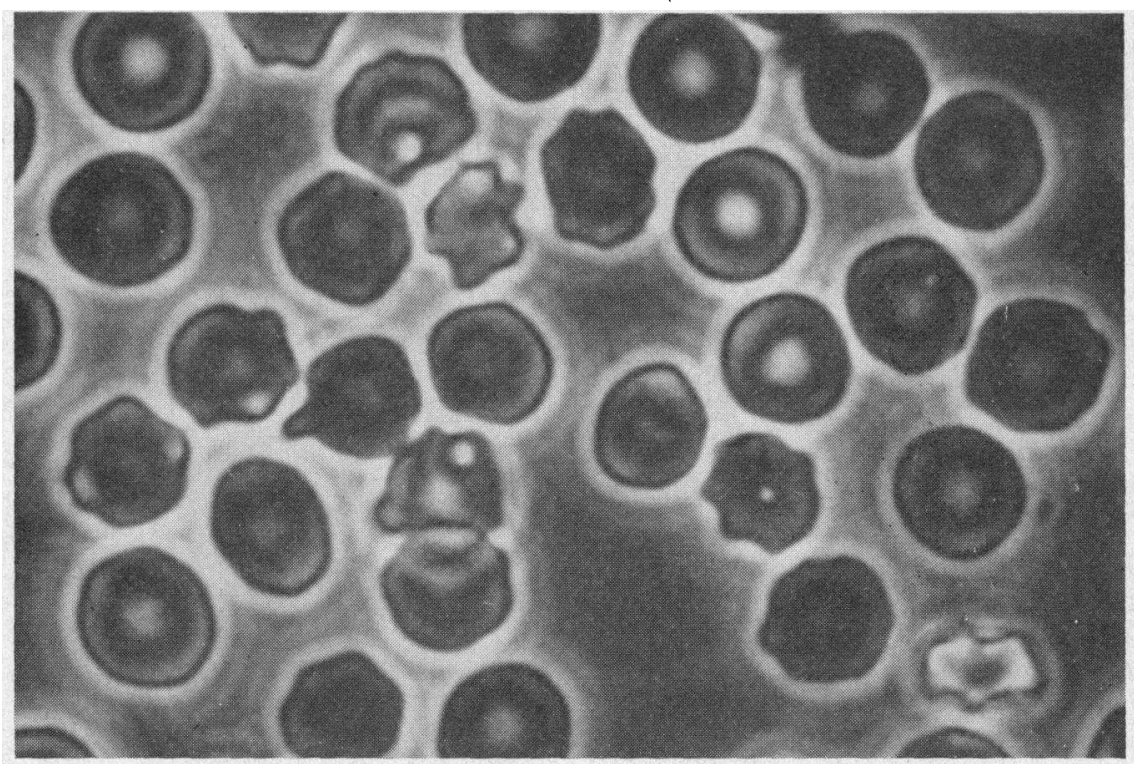

Fig. 6. Phase photomicrograph OF Fresh hereditary SPherocytosis Red Blood CELLS. Note some normal biconcave discs as well as crenation.

strate produces changes that appear to correspond to Ponder's (28) description of the disc $\rightarrow$ crenated disc $\rightarrow$ crenated sphere $\rightarrow$ sphere transformation. Crenated discs are transformed to crenated spheres and then to end stage spherocytes at 24 hours, smaller in diameter and volume and without crenation. Figures $7 \mathrm{~A}$ and $\mathrm{B}$ represent $\mathrm{HS}$ blood incubated without glucose for 5 hours. Note the marked crenation and also the extension of crenation to bud-like processes, which separate from the cells yielding. platelet-sized fragments. Under higher magnification, smaller filamentous "myelin forms" can be seen coming off the tips of the crenations. Figure 8 illustrates end stage spherocytes incubated for 24 hours without glucose. Figure 9 is an electron micrograph of normal cells incubated for 36 hours without substrate; fragmentation similar to that seen at an earlier stage in HS cells is to be seen. The end result of such membrane loss from normal cells is the production of microspherocytes that appear like the HS cells seen in Figure 8. Normal cells incubated in glucose or glucose plus ouabain for 48 hours show some crenation, but many biconcave discs can still be seen.

\section{Discussion}

The main determinant of in vitro hemolysis is the volume of the cell at any given time in relation to its maximal possible membrane surface area. In vitro osmotic fragility is dependent on: $a$ ) the suspending medium, whose $\mathrm{pH}$ and tonicity are controlled in the osmotic fragility test $; b$ ) the total number of intracellular osmotically active constituents, which determine cell volume in any given external environment; and $c$ ) the critical hemolytic volume, a complex parameter dependent on quantitative and qualitative factors associated with the membrane lipid and protein. Therefore, the important relationship determining osmotic fragility is the ratio of the critical hemolytic volume to the internal osmotic contents of the erythrocyte. If we assume a continuous bilipid layer of membrane, the lipid loss after in vitro incubation as demonstrated by Reed and Swisher $(8,9)$ and Prankerd (10) would result in a decrease in the surface area. If this decrease of surface area is in excess of the loss of osmotically active cell contents, increased osmotic fragility would inevitably result. The corollary of this is that any increase of osmotic contents would also predispose to increased sensitivity to osmotic lysis. Such an increase in the total cation content of the cell with secondary accumulation of anions but without a change in surface area has been demonstrated in the HS cells incubated with supplemental glucose and in normal cells incubated without glucose. Such cells will approach their critical volume at 

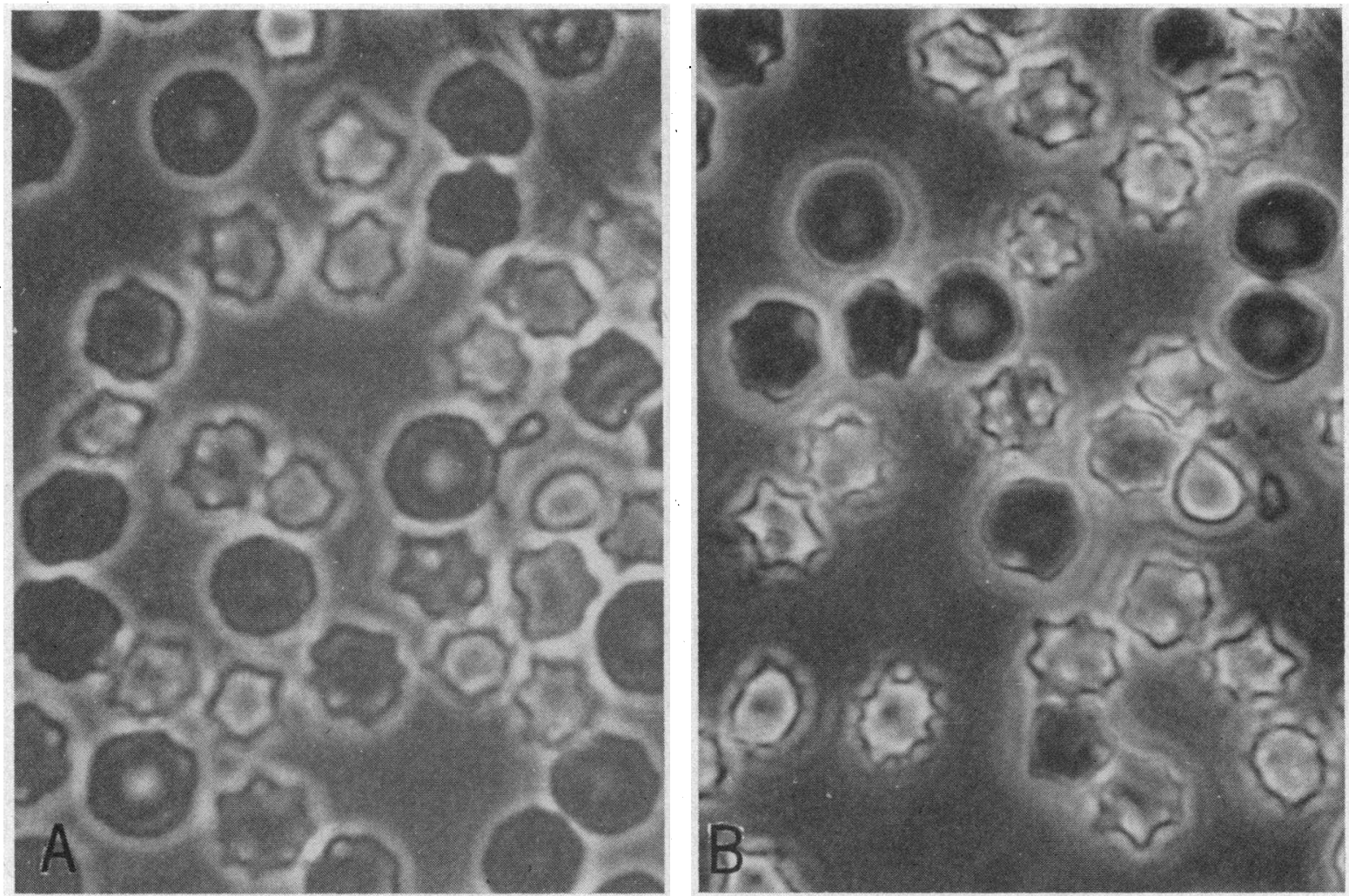

Fig. 7. PHASE PHOTOMICROGRAPH OF HEREDITARY SPHEROCYTOSIS BLOOD INCUBATED 5 HOURS IN ABSENCE OF GLUCOSE. Note fragmentation.

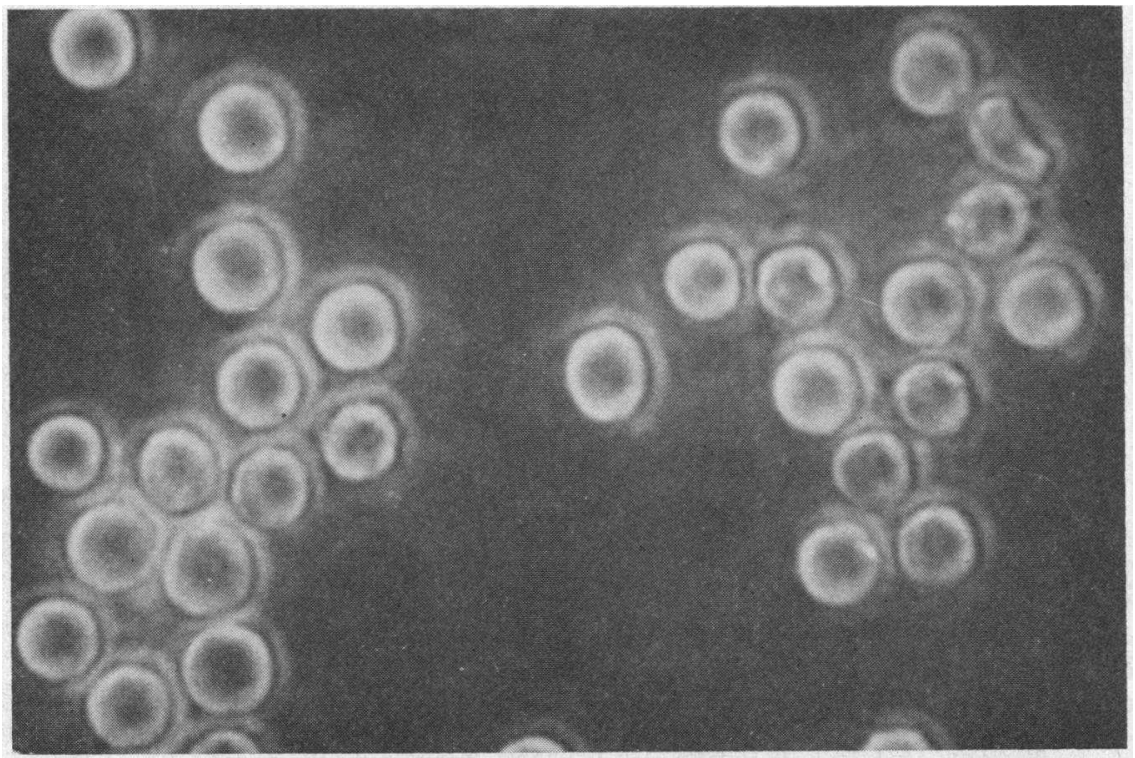

Fig. 8. PHASE PHOTOMICROGRAPH OF HEREDITARY SPHEROCYTOSIS BLOOD INCUBATED FOR 24 hours without SUBSTRATE. Note decreased size and loss of crenations. 


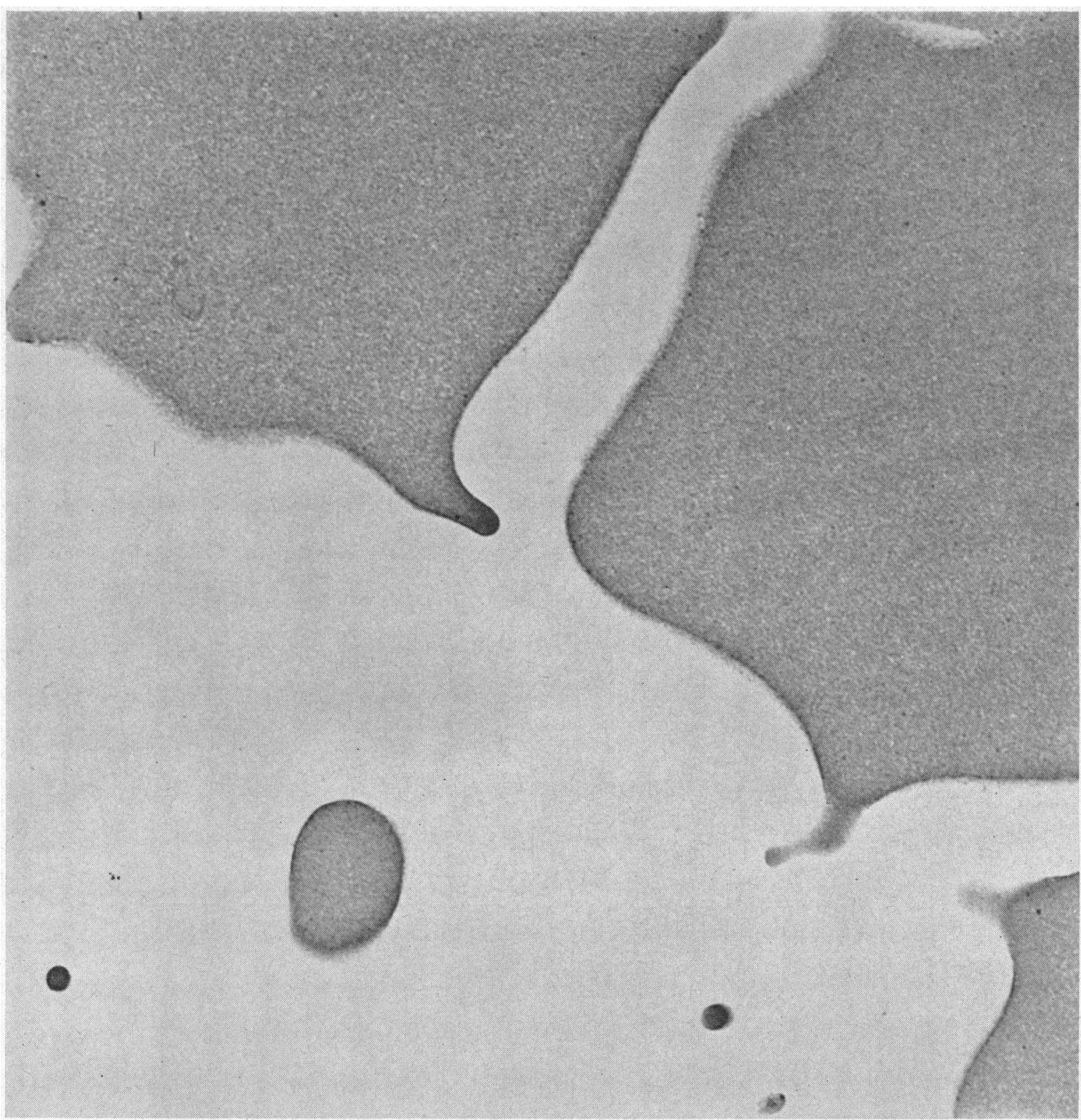

Fig. 9. EleCtron MICROGRAPH OF NORMAL ERYThrocyte SHOWING FRAGMENTATION AFTER 36 HOURS OF INCUBATION without substrate. Cells were fixed with gluteraldehyde and osmium tetraoxide, mounted in epon, and magnified 16,000 times.

a higher external tonicity than will cells with normal intracellular osmotic content. Similarly, in vitro autohemolysis in the absence of any external physical or chemical injury to the membrane may be considered analogous to osmotic lysis and result from a decrease in the ratio of critical hemolytic volume to cellular contents. Autohemolysis can be produced by any alteration that produces a marked gain in intracellular osmotic activity with swelling secondary to water gain. In the absence of osmotically dictated water gain, however, autohemolysis may result from a decrease in the critical hemolytic volume with the achievement of the hemolytic ratio of surface area to osmotic contents, even at the tonicity of plasma. Obviously, osmotic swelling plus decreased critical volume can combine to produce hemolysis. Autohemolysis secondary to a decrease in critical hemo- 
lytic volume is readily apparent in the HS cells that were incubated without the addition of glucose. Metabolically depleted HS cells were not significantly greater $(p>0.05)$ than fresh HS cells in volume or total cation content, but they underwent only slight swelling upon introduction into the buffered sodium chloride solutions of decreasing tonicity, indicating that many of the cells were close to their critical volume at an external tonicity equal to that of plasma. Consequently, in terms of the ratio of critical hemolytic volume to osmotically active cell contents, the decrease in surface area is primarily responsible for the autohemolysis of nonsupplemented, metabolically depleted HS cells. These observations provide direct support for the suggestion of Selwyn and Dacie (6) that the primary abnormality accounting for in vitro autohemolysis of nonsupplemented HS cells is a membrane alteration with decrease in surface area.

The addition of ouabain, which inhibits the sodium-potassium pump, resulted in a net accumulation of sodium but a lesser loss of potassium in the HS cells incubated with glucose plus ouabain, with a resultant increase in the cation content and volume of these cells in plasma. The glucose plus ouabain HS cells did not demonstrate any significant decrease in critical hemolytic volume and were no different in this respect from the cells that had glucose alone added. On the other hand, the HS cells incubated without added glucose also had both an increased sodium content and decreased potassium content, but the total cation content of these cells and in particular the potassium content was decreased. Both the $\mathrm{K}^{+}$ $(\mathrm{p}<0.01)$ and the $\mathrm{Na}^{+}(\mathrm{p}<0.01)$ were significantly lower than like values for the glucose plus ouabain HS cells. Thus, although swelling of the cells at 24 hours might be anticipated by virtue of a decreased activity of the sodiumpotassium pump with a secondary increase in total cation content in line with the suggestion of Tosteson (29) for the role of the pump in the maintenance of normal cell volume, this does not appear to be the case. By contrast, normal cells incubated under identical circumstances do appear to conform with the pump-leak hypothesis, showing some gain in total cation and little change in critical hemolytic volume after 24 hours of incubation under identical circumstances. It is ap- parent, however, that normal cells do undergo a decrease in critical volume after 36 to 48 hours similar to those found with HS cells after 24 hours of incubation.

Thus, protection against autohemolysis of glucose or glucose plus ouabain-supplemented HS cells appears attributable to maintenance of critical volume. Theoretically, even in the face of a decrease in critical volume as seen with depleted HS cells, if the cell water (or effective osmotic activity) were lowered sufficiently, autohemolysis could also be prevented by maintaining the ratio of critical volume to osmotic contents below the point of autohemolysis. Observations of Jacob and Jandl (12) on the protection of depleted HS cells against autohemolysis by added sucrose or by substitution of choline for sodium are consistent with this alternative mode of protection against autohemolysis.

Reed and co-workers $(8,9,30)$ have shown that the exaggerated loss of lipid from HS cells involves all the phospholipids and cholesterol in the proportions in which they are found in the intact red cell membrane. This proportionate loss of membrane lipid and the apparently paradoxical exaggerated loss of both potassium and total cation are consistent with the morphological finding of fragmentation after crenation. Fragments may not only contain lipid but possibly cation as well and thus provide an explanation for cell volume being unchanged at 24 hours in spite of the early increase in volume secondary to $\mathrm{Na}^{+}$accumulation described by Jacob and Jandl (12). Although metabolically depleted normal cells will undergo a similar disc-sphere transformation with loss of lipid and reduction of critical volume after incubation for 36 to 48 hours, the hereditary spherocyte seems to manifest these changes more rapidly. The interchangeability of adenosine, inosine, and glucose as substrates to maintain the integrity of hereditary spherocytes, as well as the demonstration of Jaffé and associates (31) that adenine nucleotides help protect the normal red cell against osmotic lysis when incubated in vitro, suggests that ATP is essential for maintenance of the membrane lipid and critical hemolytic volume.

The addition of ouabain in no way interferes with this protective action of glucose and therefore, presumably ATP in terms of stabilizing the structure of the membrane. Thus the sodium- 
potassium pump ATPase does not appear to be involved in this process. In considering the shape changes, however, Nakao and co-workers $(32,33)$ have presented evidence to indicate that the discsphere transformation of normal cells may be produced by lowering of cellular ATP levels. Since HS cells have an increased requirement of ATP for transport (12), they may also have a similarly increased requirement for maintenance of shape.

Fragmentation of normal erythrocytes after prolonged in vitro incubation was first described by Meltzer and Welch $(34,35)$ and characterized in great detail by Ponder (28). A postulated sequence for the in vitro events described for the HS cell would be initiated by ATP depletion. Initial swelling secondary to accumulation of $\mathrm{Na}^{+}$ as described by Jacob and Jandl (12) would be accompanied by crenation as ATP disappeared. Since a biomolecular layer of lipid is physically the most stable configuration (36), marked crenation may actually lead to small areas having, at the tips of crenations, quadrimolecular lipid layers leading to submicroscopic losses of lipid. The fact that normal cells incubated for 24 hours with glucose show some crenation and lipid loss but no decrease in critical hemolytic volume is consistent with such a notion. Maintenance of critical volume, in spite of some lipid loss, must mean that the critical volume also depends on the structural membrane protein, the organization of which in turn may relate to ATP levels. Finally, gross fragmentation of the depleted HS cell becomes evident with further losses of lipid and $\mathrm{K}^{+}$. However, the relative importance of fragmentation evident by light microscopy versus that not evident with the light microscope remains to be determined. In any case, decrease of surface area and a steady decrease in critical hemolytic volume occur and finally lead to the smooth microspherocyte. Thus, the well-known changes in osmotic fragility and autohemolysis of metabolically depleted HS cells would appear to be related to the marked changes in the cell membrane as postulated by Selwyn and Dacie (6). In addition to an increased $\mathrm{Na}^{+}$influx (11) and increased pump flux at normal intracellular $\mathrm{Na}^{+}$levels (12), the fresh HS cell from splenectomized patients has a decreased critical hemolytic volume and increased predisposition to undergo disc-sphere shape changes in spite of a normal lipid and total cation content $(8,9)$. Thus, the basic defect may reside with the membrane protein and its ouabain insensitive as well as ouabain sensitive ATPase activities. Tosteson (37) has called attention to the genetic linkage and correlation between pump ATPase activity and cation leakiness in sheep cells. The increased permeability of HS cells may represent a similar example of such a genetic correlation between increased cation leakiness and increased pump ATPase activity involving the ouabain insensitive ATPase as well.

\section{Summary}

Alterations in osmotic fragility and in vitro autohemolysis observed in both normal erythrocytes and hereditary spherocytes can best be understood in terms of the relationship between critical hemolytic volume and intracellular osmotic activity. Evidence has been presented for a ouabain insensitive membrane requirement for glucose. Both normal cells and hereditary spherocytes when metabolically depleted undergo the disc-sphere transformation described by Nakao and his associates. These shape changes are associated with a concomitant loss of membrane material manifested as a physical fragmentation.

The hereditary spherocyte differs from the normal cell in that this degenerative loss of membrane material is much accelerated compared with the normal when both are incubated without added glucose. We suggest that the primary defect may be an abnormality in the membrane protein of hereditary spherocytes.

\section{Acknowledgments}

We wish to thank Dr. Charles Yuile for his electron micrographs of normal cells incubated for 36 hours and Miss Ann Gregory, Mrs. Sonja Valkenburg, and Miss Donna Meisenzahl for their technical assistance in carrying out the experiments.

\section{References}

1. Haden, R. L. The mechanism of the increased fragility of the erythrocytes of congenital hemolytic jaundice. Amer. J. med. Sci. 1934, 188, 441.

2. Castle, W. B., and G. A. Daland. Susceptibility of erythrocytes to hypotonic hemolysis as a function of discoidal form. Amer. J. Physiol. 1937, 120, 371. 
3. Dacie, J. V., and J. M. Vaughan. The fragility of the red blood cells: its measurement and significance. J. Path. Bact. 1938, 46, 341.

4. Sharpsteen, J. R., Jr. Physico-chemical mechanisms in the pathogenesis of certain hemolytic anemias. Amer. J. med. Sci. 1955, 229, 506.

5. Dacie, J. V. Observations on autohaemolysis in familial acholuric jaundice. J. Path. Bact. 1941, 52, 331.

6. Selwyn, J. G., and J. V. Dacie. Autohemolysis and other changes resulting from the incubation in vitro of red cells from patients with congenital hemolytic anemia. Blood 1954, 9, 414.

7. Young, L. E., M. J. Izzo, K. I. Altman, and S. N. Swisher. Studies on spontaneous in vitro autohemolysis in hemolytic disorders. Blood 1956, 11, 977.

8. Reed, C. F., and S. N. Swisher. Abnormalities of in vitro behavior of structural lipids of red blood cells from patients with hereditary spherocytosis (abstract). J. clin. Invest. 1960, 39, 1019.

9. Reed, C. F., and S. N. Swisher. Erythrocyte lipid loss in hereditary spherocytosis. J. clin. Invest. 1966, 45, 777.

10. Prankerd, T. A. J. Studies on the pathogenesis of haemolysis in hereditary spherocytosis. Quart. J. Med. 1960, 29, 199.

11. Bertles, J. F. Sodium transport across the surface membrane of red blood cells in hereditary spherocytosis. J. clin. Invest. 1957, 36, 816.

12. Jacob, H. S., and J. H. Jandl. Increased cell membrane permeability in the pathogenesis of hereditary spherocytosis. J. clin. Invest. 1964, 43, 1704.

13. Parpart, A. K., P. B. Lorenz, E. R. Parpart, J. R. Gregg, and A. M. Chase. The osmotic resistance (fragility) of human red cells. J. clin. Invest. 1947, 26, 636.

14. Garby, L., and C. H. de Verdier. Glucose metabolism in normal erythrocytes. I. Kinetics of the hexokinase reaction in intact cells. Scand. J. Haemat. 1964, 1, 150.

15. Simon, E. R., and P. Ways. Incubation hemolysis and red cell metabolism in acanthocytosis. J. clin. Invest. 1964, 43, 1311.

16. Hoffman, J. F. Cation transport and structure of the red-cell plasma membrane. Circulation 1962, 26, 1201.

17. Lepke, S., and H. Passow. Effects of temperature, alkaline earth metal ions, and complexing agents of the hemolytic medium on potassium permeability of erythrocyte ghosts (abstract). Pflügers Arch. ges. Physiol. In press.

18. Murphy, J. R. Erythrocyte metabolism. II. Glucose metabolism and pathways. J. Lab. clin. Med. 1960, 55, 286.

19. Brecher, G., E. F. Jakobek, M. A. Schneiderman, G. Z. Williams, and P. J. Schmidt. Size distribution of erythrocytes. Ann. N. Y. Acad. Sci. 1962, 99, 242.
20. Weed, R. I., C. F. Reed, and G. Berg. Is hemoglobin an essential structural component of human erythrocyte membranes? J. clin. Invest. 1963, 42, 581.

21. Valberg, L. S., J. M. Holt, E. Paulson, and T. Szivek. Spectrochemical analysis of sodium, potassium, calcium, magnesium, copper and zinc in normal human erythrocytes. J. clin. Invest. 1965 , 44, 379.

22. McElroy, W. D., and H. H. Seliger. The chemistry of light emission. Advanc. Enzymol. 1963, 25, 119.

23. Tosteson, D. C., P. Cook, and R. Blount. Separation of adenosine triphosphatase of $\mathrm{HK}$ and $\mathrm{LK}$ sheep red cell membranes by density gradient centrifugation. J. gen. Physiol. 1965, 48, 1125.

24. Tal, E., S. Dikstein, and F. G. Sulman. ATP determination with the Tricarb scintillation counter. Experientia (Basel) 1964, 20, 652.

25. Mohler, D. N. Adenosine triphosphate metabolism in hereditary spherocytosis. J. clin. Invest. 1965, 44, 1417.

26. Keitt, A. S. Changes in the content and ${ }^{32} \mathrm{P}$ incorporation of glycolytic intermediates during incubation of normal and hereditary spherocytosis erythrocytes. Brit. J. Haemat. 1965, 11, 177.

27. Guest, G. M. Osmometric behavior of normal and abnormal human erythrocytes. Blood 1948, 3, 541.

28. Ponder, E. Hemolysis and Related Phenomena. New York, Grune \& Stratton, 1948, p. 168.

29. Tosteson, D. C. Regulation of cell volume by sodium and potassium transport in The Cellular Functions of Membrane Transport, J. F. Hoffman, Ed. New Jersey, Prentice-Hall, 1964, p. 3.

30. Weed, R. I., A. J. Bowdler, and C. F. Reed. Metabolic dependence of erythrocyte membrane structure. Clin. Res. 1965, 13, 284.

31. Jaffé, E. R., B. A. Lowy, G. A. Vanderhoff, P. Aisen, and I. M. London. The effects of nucleosides on the resistance of normal human erythrocytes to osmotic lysis. J. clin. Invest. 1957, 36, 1498.

32. Nakao, M., T. Nakao, and S. Yamazoe. Adenosine triphosphate and maintenance of shape of human red cells. Nature (Lond.) 1960, 187, 945.

33. Nakao, M., T. Nakao, S. Yamazoe, and H. Yoshikawa. Adenosine triphosphate and shape of erythrocytes. J. Biochem. (Tokyo) 1961, 49, 487.

34. Meltzer, S. J. The effects of shaking upon the red blood cells. Johns Hopk. Hosp. Rep. 1900, 9, 135.

35. Meltzer, S. J., and W. H. Welch. The behaviour of the red blood-corpuscles when shaken with indifferent substances. J. Physiol. (Lond.) 1884, 5, 255.

36. Thompson, T. E. The properties of bimolecular phospholipid membranes in Cellular Membranes in Development, M. Locke, Ed. New York, Academic Press, 1964, p. 83.

37. Tosteson, D. C. Active transport, genetics, and cellular evolution. Fed. Proc. 1963, 22, 19. 